\title{
Root foraging strategies and soil patchiness in a humid savanna
}

\author{
P. Mordelet, S. Barot ${ }^{1}$ and L. Abbadie \\ Ecole Normale Supérieure, Laboratoire d'Ecologie, CNRS URA-258, 46 rue d'Ulm, F-75230 Paris cedex 05, \\ France. ${ }^{~}$ Corresponding author*
}

Received 20 July 1995. Accepted in revised form 18 March 1996

Key words: Borassus aethiopum, Côte d'Ivoire, foraging, heterogeneity, humid savanna, Lamto, nutrients, root, spatial structure, West Africa

\begin{abstract}
In Lamto (Côte d'Ivoire), the savanna is a patchy environment as far as soil is concerned: tree clumps and termite mounds lead to higher nutrient contents than in the surrounding savanna. Mature Borassus aethiopum (Mart.) specimens are tall palm trees dominating the community, with aerial parts located out of these nutrient-rich patches.

Palm root densities were compared under tree clumps and in the surrounding savanna, and were also sampled along transects between palm trees and nutrient-rich patches (two clumps and one mound). Palm root densities were far higher (up to 10 times) in the nitrogen-rich soil of both clumps and termite mounds than in the surrounding savanna. Evidence is given that palm trees are able to extend their root system as far as $20 \mathrm{~m}$ towards these nutrient-rich patches where they proliferate. These results point out a particular root foraging strategy, which is one of the first known for a woody perennial. They also provide new insights for understanding nitrogen cycling and savannas high rate of primary production.
\end{abstract}

\section{Introduction}

Resource acquisition is a fundamental challenge for every living organism, particularly for plants because they are immobile (Harper, 1977). Access to soil nutrients requires that plants explore their environment through elongation and ramification of their root system. When a nutrient rich patch is reached, root functioning may be altered to improve resource exploitation. This requires phenotypic plasticity, involving changes in the pattern of extension, ramification, dynamics, and physiology of the root system (Hutchings, 1988). Soil exploration patterns have been described as "root foraging strategies", and have widely been studied through theoretical and experimental approaches. Yet, these experiments refer to situations where soil nutrient heterogeneity has been artificially created (Hutchings, 1988) and cannot really point out the impact of plant root foraging strategies for ecosystem functioning.

* FAX No: +33144323885
Savannas are naturally very heterogeneous ecosystems, with low nutrient content in the bulk soil, considered to limit primary production (Bate, 1981), but including nutrient rich patches under trees (Mordelet et al., 1993) or termites mounds (Abbadie et al., 1992a). Consequently, they provide a relevant field situation to show peculiar root foraging strategies. The study aims to determine the foraging strategy of a palm tree, Borassus aethiopum (Mart.), the aerial parts of which are located outside of nutrient-rich patches. The palm root system was investigated in the nutrient-rich soil and in the surrounding savanna.

\section{Study area}

The study was conducted at the Tropical Ecology Station of Lamto, Côte d'Ivoire $\left(6^{\circ} 13^{\prime} \mathrm{N}, 5^{\circ} 02^{\prime} \mathrm{W}\right)$. Mean annual temperature is $27^{\circ} \mathrm{C}$ and rainfall averages 1200 $\mathrm{mm}$ a year (data from Lamto Geophysical Station). The dry season occurs in December and January. Soils are ferralsols (FAO classsification) with $80-90 \%$ sand and 
a very low organic matter and nitrogen content (1\% and $0.5 \%$ respectively).

Tree density increases along the catena, from grass savanna in bottomlands to savanna woodland on plateaus (Menaut and César, 1982). The intermediary savanna facies is the most widespread and was choosen for the study. This facies is made of small trees (up to $10 \mathrm{~m}$ ), mainly gathered in clumps and scattered over a continuous grass layer. Both grass and tree layers are dominated by adult palm trees, Borassus aethiopum (Mart.), up to $20 \mathrm{~m}$ tall and with a broad crown of palm leaves (about $5 \mathrm{~m}$ in diametre). They are excluded from tree clumps. This exclusion, clearly shown by field observations, is attributed to light limitation for seedlings. Their life span was assessed to be over 90 years (R. Vuattoux, pers. commun.).

The nutrient distribution was shown to be very patchy in this savanna. At the 10 to $100 \mathrm{~m}^{2}$ scale, the nutrient enriched patches are located under clumps (Mordelet et al., 1993) and mounds (Abbadie et al., 1992a). Clumps are considered to be favoured and maintained by fire (Hochberg et al., 1994; Menaut et al., 1990) and mounds are mainly attributed to termite activity.

\section{Materials and methods}

A total of 27 soil blocks were randomly excavated under 6 tree clumps (hereafter called the canopy situation), and 27 blocks outside the same clumps (open situation, $3 \mathrm{~m}$ outside the canopy edge). Most of the blocks were excavated to $60 \mathrm{~cm}$ depth because clumps and mounds induce nutrient enrichment mainly in the shallow soil layers; 6 of the 27 blocks were performed down to $120 \mathrm{~cm}$ in each situation. Soil blocks were excavated within a $20 \mathrm{~cm} \times 20 \mathrm{~cm}$ frame, in 10$\mathrm{cm}$ depth increments (in the first $10 \mathrm{~cm}, 0-5$ and 5$10 \mathrm{~cm}$ were distinguished). This part of the study was performed from April 1989 to February 1990. Each month, both canopy and open situations of the same selected tree clumps were sampled. The selected tree clumps were made of three species, Bridelia ferruginea Benth., Crossopteryx febrifuga (Afzel. ex G. Don) Benth., Cussonia barteri Seeman and without any B. aethiopum (Mordelet and Menaut, 1995).

In addition, 3 transects were chosen between a nutrient rich patch and the single closest adult palm. Two transects were sampled between a palm and a clump ( $12 \mathrm{~m}$ and $18 \mathrm{~m}$ long) and one transect between a palm and a mound ( $24 \mathrm{~m}$ long). For each stop along the transects, three soil samples were collected in order to account for lateral variability, systematically avoiding grass tufts to prevent a grass tuft effect on root density variations. Soil cores were extracted with an auger $(7.15 \mathrm{~cm}$ in diameter) down to $60 \mathrm{~cm}$ in $10 \mathrm{~cm}$ increments. For each transect and for each depth, two additional cores were collected, in the open and canopy situations, respectively, to assess total soil nitrogen content. The roots were extracted by washing the soil samples on a $1 \mathrm{~mm}$ mesh sieve, then by floating to separate the roots from the remaining mineral particles, and finally dried. B. aethiopum roots, which are easy to identify due to their black rhizoderm and particular morphology, were manually extracted and then weighed. Roots were not sorted into size classes because the rhizoderm was often partly separated from the core of the root.

Total $\mathrm{N}$ content was measured by the Kjeldhal method (oxidation by sulfuric acid and liberation of amonium by steam distillation in the presence of excess $\mathrm{NaOH}$ and titration with $\mathrm{HCl}$ using methylred indicator) with a Kjeltec Auto Analyser apparatus.

Statistical analyses were performed with SAS package. Root densities along the transects were submitted to the default bivariate interpolation method of G3GRID that compels the interpolated surface, drawn by GCONTOUR procedure (Fig. 2), to pass precisely through data points (SAS, 1990a). For each transect, the significance of the linear model, including the position and depth effects on root densities was assessed with GLM procedure. It uses the least square methed to fit general linear models for unbalanced designs (SAS, 1990b). Sums of square of type III have been used. The logarithm of the dependent variable (root density) has been used so that the residuals of the model could be considered independent from each other, and having a constant variance.

\section{Results}

B. aethiopum root densities, expressed in $\mathrm{kg}$ (roots) $\mathrm{m}^{-3}$ (soil), were significantly higher under the canopy than in the open situation (Fig. 1), for all depths above $50 \mathrm{~cm}$, except for the $0-5 \mathrm{~cm}$ layer ( $\mathrm{t}$ test, $p<0.05$ ). Between 0 and $60 \mathrm{~cm}$ depth, their cumulative root phytomass was about 3 times higher under the canopy than in the open $\left(328 \mathrm{~g} \mathrm{~m}^{-2}\right.$ and $121 \mathrm{~g} \mathrm{~m}^{-2}$ respectively). Root densities increased with depth and reached a maximum between 30 and $50 \mathrm{~cm}$ and the profiles 




Figure 1. (a) Distribution of palm root densities between 0 and $120 \mathrm{~cm}$ depth in the open and canopy situations with associated standard errors ( $n=27$ between 0 and $60 \mathrm{~cm}$ depth, $n=6$ under $60 \mathrm{~cm}$ depth). (b) The foraging index (F.I.) was defined as mean root density in the canopy situation / mean root density in the open situation. The fitted curve equation is F.I $=10.8 \times \mathrm{e}^{0.03 d e p t h}, \mathrm{R}^{2}=0.855$.

were not significantly different in canopy and in open situations.

B. aethiopum root distribution is quite similar for all transects (Fig. 2). In the open palm roots were very scarce and only located in the deeper layers (below $30 \mathrm{~cm}$ ), whereas they occurred throughout the profile under the clumps, the mound, and around palm tree bottoms. In agreement with the soil block data, root densities were higher under the tree clumps and the mounds than in the bulk savanna. This result is emphasized by a significant effect of the distance from the palm tree on each transect (Table 1). However, the highest palm root densities occurred within a $2-3 \mathrm{~m}$ radius around palm tree bases.

The mean total $\mathrm{N}$ content between 0-60 cm depth was ( $t$ test, $\mathrm{p}<0.05$ ) higher under the tree clumps and the mounds than in open savanna (Fig. 3). Total N content decreased with depth in both the open savanna and under the nutrient-rich patches.

\section{Discussion}

Both sampling procedures showed similar root density values. Moreover, they both exhibited higher root densities under heterogeneity sources (tree clumps and mounds) than in the bulk savanna. Because the blocks were randomly located both in canopy and open situations, the comparison between these situations points out that the high palm root densities were restricted to the clump area. Consequently, the high palm root densities observed under clumps and mounds can only result from the root proliferation of the studied palm or of another palm even farther away, and cannot result from an uniform distribution of their roots. Thus, the palm root system appears to be composed of three parts: a high density root part within $3 \mathrm{~m}$ of the $B$. aethiopum base, an extensive low root density part radiating from the stem and leading to a high root density part under clumps and mounds.

The major feature, shared by clumps and termite mounds, was the high soil nitrogen content. The differences between canopy and open situation measured on the transects were consistent with previous results obtained in Lamto savanna on clumps (Mordelet et al., 1993) and termite mounds (Abbadie et al., 1992a) and showing high microbial activity resulting in a high availability of nitrogen. The proliferation of palm roots is clearly related to this improvement of soil nutrient status as shown by the high foraging index of the upper soil layers (Fig. 1b). Actually, fine rootlets, responsible for nutrient uptake, were partly lost by sieving, but a strong positive correlation can be assumed between fine rootlet and collected root densities. Consequently, root proliferation under clumps or termite mounds likely enhances nutrient uptake. Furthermore, the palm root foraging strategy results in both a large area prospected, and in a high efficiency of resource exploitation because high root densities only cccur in nutrient rich patches. This decreases the cost of nutrient uptake and could be of great importance for palms because the low soil nutrient content of the savanna was thought to limit primary production (Bate, 1981). 


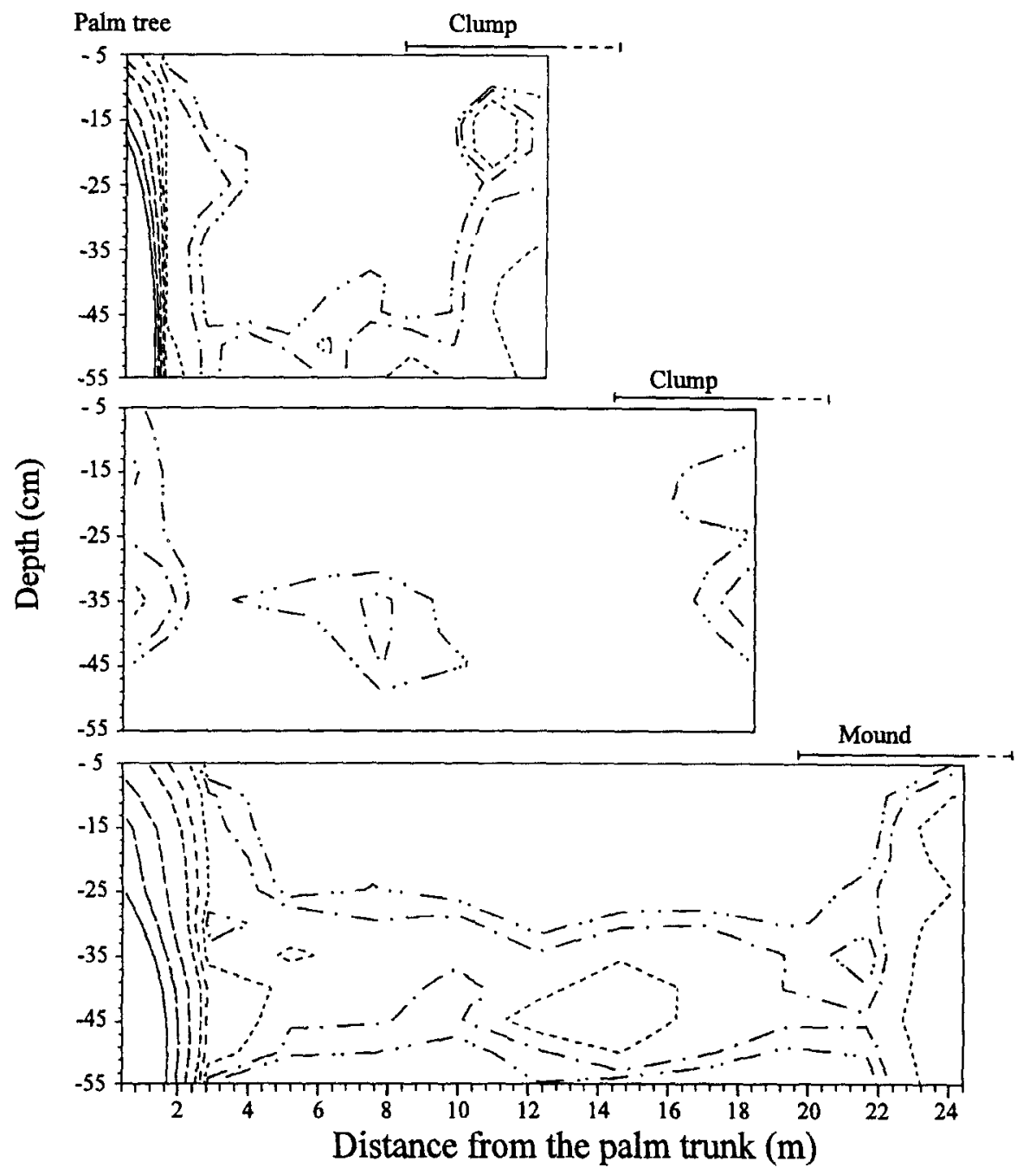

\section{Palm root density

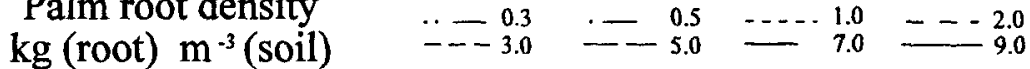

Figure 2. Palm tree root iso-densities between 0 and $60 \mathrm{~cm}$ along transects between a nutrient rich patch (two tree clumps and one mound) and an adult palm. See text for explanations about the interpolation method

Table 1. Significance of the linear model for the transects ( $F$ test), including position, depth effects and their interactions. The first $3 \mathrm{~m}$ of the transect, with high root density values near palm trunks, were not used in the analyse to point out only differences between heterogeneity sources (two clumps and one mound) and the bulk savanna. The d.f. for each factor are indicated in parenthesis. The total d.f. (for the total sum of square) are respectivly, for each transect, 191,177 and 115

\begin{tabular}{llllll}
\hline Transects & $\mathrm{R}^{2}$ & Model & Position & Depth & Position $\times$ depth \\
\hline Mound $(24 \mathrm{~cm})$ & 0.717 & 0.0001 & $0.0001(10)$ & $0.0001(5)$ & $0.0229(50)$ \\
Clump $(18 \mathrm{~m})$ & 0.540 & 0.0015 & $0.0001(11)$ & $0.0113(5)$ & $0.3251(52)$ \\
Clump $(12 \mathrm{~m})$ & 0.575 & 0.0003 & $0.0002(16)$ & $0.0001(5)$ & $0.1258(29)$ \\
\hline
\end{tabular}






Figure 3. Soil nitrogen content between 0 and $60 \mathrm{~cm}$ depth in the bulk savanna and in the nutrient rich patches (two clumps and one mound) for the transects, with associated standard errors $(n=3)$.

Proliferation of roots in nutrient patches has widely been recognized in laboratory studies (Campbell et al., 1991a, 1991b; Drew, 1975; Gersani and Sachs, 1992; Gross et al., 1993), controled field experiments (Caldwell et al., 1991; Jackson et al., 1990; Pregitzer et al., 1993), or theoretical models (Berntson, 1994; Oborny, 1994; Sutherland and Stillman, 1988). These studies are based on artificially created heterogeneity and mainly deal with herbaceous plants, and are not relevant to draw conclusions at the ecosystem level. The present study provides results on a long-lived woody perennial under field conditions. The proliferation of its roots is likely to be a widespread phenomenon. In Lamto savanna, due to the spatial distribution of palm trees, clumps, and termite mounds, each adult palm exploiting large patches ranging from 10 to $100 \mathrm{~m}^{2}$, 10 to $20 \mathrm{~m}$ away from their trunk - is likely to reach at least one nutrient patch, and conversely each nutrient patch is likely to be exploited by at least one palm tree.

Palm trees appear as a nutrient sink for clumps and mounds, especially for nitrogen, because they export nutrients from these patches to their roots and above-ground parts. Yet, the palm root foraging strategy strenghtens root agregation beneath the clumps where the highest tree root densities are also observed. This spatial concentration of living and dead roots could favour quick recycling of nitrogen derived from dead root mineralization and limit nutrient loss as has been shown on perennial tuft grass in Lamto savanna (Abbadie et al., 1992b). In addition fine roots are likely to have a high turn-over in nutrient rich patches (Gross et al., 1993; Pregitzer et al., 1993) which should further enhance soil organic matter content. This overall process reinforces savanna spatial heterogeneity. Finally, this aggregative structure of underground vegetation could be crucial for nutrient dynamics and the efficiency of nutrient use at the ecosystem level. It could explain the high primary productivity of some ecosystems in spite of their low soil fertility. In fact, in a stable natural ecosystem such as Lamto, the primary productivity is not only controled by the pool of available nutrients. The actual soil fertility results both from a spatial concentration of assimilable nutrients and from the plants ability to exploit efficiently these nutrient rich patches, via their root foraging strategies. This could be of importance for savanna management.

\section{Acknowledgements}

We express our gratitude to the National University of Côte d'Ivoire and to R Vuattoux, Director of the Station, for the facilities we were given and for many interesting discussions. We warmly thank Lamto technicians for their efficient assistance at Lamto Research Station. The total $\mathrm{N}$ analysis were realized by Ginette Guillaume. We thank Michael Hochberg, Yannis Michalakis, and Michel Loreau for their relevant comments on the initial manuscript. The work was sup- 
ported by grants from the CNRS (SALT-IGBP/GCTE Core Research Program).

\section{References}

Abbadie L, Lepage M and Le Roux X 1992a Soil fauna at the forest-savanna boundary: role of the termite mounds in nutrient cycling. In Nature and Dynamics of Forest Savanna Boundaries. Eds. P A Furley, J Proctor and J A Ratter. pp 473-484. Chapman and Hall, London UK.

Abbadie L, Mariotti A and Menaut J-C 1992b Independence of savanna grasses from soil organic matter for their nitrogen supply. Ecology 73, 608-613.

Bate GC 1981 Nitrogen cycling in savanna ecosystems. In Terrestrial Nitrogen Cycles. Eds. F E Clark and T Roswall. pp 463-475: Ecol. Bull., Stockholm, Sweden.

Berntson G M 1994 Modelling root architecture: are there tradeoffs between efficiency and potential of resource acquisition? New Phytol. 127, 483-493.

Caldwell M M, Manwaring J H and Durham S L 1991 The microscale distribution of neighbouring plant roots in fertile soil microsites. Funct. Ecol. 5, 765-772.

Campbell B D, Grime J P, Mackay J M L and Jailli A 1991 a The quest for a mechanistic understanding of resource competition in plant communities: the role of experiments. Funct. Ecol. 5, 241-253.

Campbell B D, Grime J P and Mackey J M L 1991b A trade-off between scale and precision in resource foraging. Oecologia 87. 532-538.

Drew M C 1975 Comparison of the effects of a localized supply of phosphate, nitrate, amonium and potassium on the growth of the seminal root system, and the shoot, in barley. New Phytol. $75,479-490$.

Gersani M and Sachs T 1992 Development correlation between roots in heterogeneous environments. Plant Cell Environ. 15, $463-469$.

Gross K L, Peters A and Pregitzer K S 1993 Fine root growth and demographic responses to nutrient patches in four old-field plant species. Oecologia 95, 61-64.
Harper J L 1977 Population Biology of Plants. Academic Press, London, UK.

Hochberg M E, Menaut J-C and Gignoux J 1994 The influence of tree biology and fire in the spacial structure of the West African savannah. J. Ecol. 82, 217-226.

Hutchings M J 1988 Differential foraging for resources and structural plasticity in plants. Trends Ecol. Evol. 3, 200-204.

Jackson R B, Manwaring J H and Caldwell M M 1990 Rapid physiological adjustement of roots to localized soil enrichment. Nature $344,58-60$.

Menaut J-C and César J 1982 The structure and dynamics of a West African savanna. In Ecology of Tropical Savannas. Eds. B J Huntley and B H Walker. pp 80-100. Springer-Verlag, Berlin, Germany.,

Menaut J-C, Gignoux J, Prado C and Clobert J 1990 Tree community dynamics in a humid savanna of Côte d'lvoire: modelling the effects of fire and competition with grass and neighbours. J. Biogeogr. 17, 471-481.

Mordelet P, Abbadie L and Menaut J-C 1993 Effects of tree clumps on soil characteristics in a humid savanna of West Africa (Lamto, Côte d'Ivoire). Plant and Soil 153, 103-111.

Mordelet $P$ and Menaut J-C 1995 Infuence of trees on above-ground production dynamics of grasses in a humid savanna. J. Veg. Sci., $6,223-228$.

Oborny B 1994 Growth rules in clonal plants and environmental predictability - a simulation study. J. Ecol. 82, 341-351.

Pregitzer K S, Hendrick R L and Fogel R 1993 The demography of fine roots in response to patches of water and nitrogen. New Phytol. 125, 575-580.

SAS 1990a G3GRID, GCONTOUR procedures. In SAS/GRAPH user's guide, version 6, Vol. 2. pp 867-888, 1311-1330. SAS Institute Inc., Cary, USA.

SAS 1990b GLM procedure. In SAS/STAT software, version 6, Vol. 2. pp 891-996. SAS Institute Inc., Cary, USA.

Sutherland W J and Stillman R A 1988 The foraging tactics of plants. Oikos 52, 239-244.

Section editor: $G R$ Stewart 